\title{
The first record of the Speckled shrimp Metapenaeus monoceros (Fabricius, 1798) (Crustacea: Decapoda: Penaeidae) from the Iranian coastal waters
}

\author{
Mohsen Safaie ${ }^{1 *}$, Mohammad Momeni $^{2}$ and Ashkan Azhdahakoshpour ${ }^{3}$
}

\begin{abstract}
Background: Penaeid shrimps are widely distributed in the tropical and sub-tropical areas of the world. These family is represented with 13 species (about six genera) in the Iranian coast (Persian Gulf and Gulf of Oman). This is two species of the genus Metapenaeus Wood-Mason \& Alcock, 1891, was reported from the areas included Metapenaeus affinis (H. Milne Edwards, 1837) and Metapenaeus stebbengi Nobili, 1904.

Methods: Four adult specimens including three female and one male specimens of Metapenaeus monoceros (Fabricius, 1798), were collected by bottom trawl in January 2013 from the Gulf of Oman, the Iranian coast. The specimens were identified by external morphological characters.

Results: In the present study, we report M. monoceros from the Iranian coast of the Gulf of Oman. The present material represents the first record of the species from this area.

Conclusion: Until now, only two species of the genus Metapenaeus Wood-Mason \& Alcock, 1891, was reported from the areas. This species is native to the Indo-West Pacific region. Now recorded from the Iranian coasts.
\end{abstract}

Keywords: Metapenaeus monoceros, First record, Gulf of Oman, Iran

\section{Background}

Penaeid prawns (shrimps) are widely distributed in the tropical and sub-tropical areas of the world. They are particularly abundant in Southeast Asia, India, Gulf of Mexico, Australia and the Persian Gulf (Fischer and Bianchi 1984). Major research on the decapod crustaceans of the Iranian coastal waters was effectively initiated by Heller (1861). Decapod crustaceans were subsequently reported from Iran by Alcock (1895, 1896, 1898, 1899a, 1899b, 1900, 1901, 1905), who studied materials collected in the region by the Royal Indian research vessel, 'Investigator'. Nobili (1905; 1906) published a list of decapods from the Persian Gulf in 1901. The Danish Scientific Investigations carried out in 1937 and 1938, conducted a comprehensive fisheries study along the coasts of Iran, and produced among other results

\footnotetext{
*Correspondence: msn_safaie@yahoo.com

${ }^{1}$ Fisheries Department, University of Hormozgan, Bandar Abbas, PO Box 3995, IR, Iran

Full list of author information is available at the end of the article
}

an important work on the brachyuran fauna of the Gulf (Stephensen 1946). Haig (1966) studied the porcellanids collected from the Persian Gulf and Gulf of Oman based on the collection of the Danish Expedition (1937-38), as did Banner and Banner (1981) with the alpheid shrimps. Apel (2001) reviewed the previous records of the decapoda from the Persian Gulf and its adjacent waters. Naderloo and Türkay (2012) subsequently reported decapods from the littoral and shallow sublittoral Iranian coast of the Persian Gulf.

A study conducted by Carpenter et al. (1997) on the penaeid shrimps revealed that nine species of this family can be found in the Persian Gulf. The only study on the identification and distribution of penaeid shrimps by Safaie and Kamrani (2009) from the Iranian waters, 13 species of Penaeidae, have been reported in coastal waters of Persian Gulf and Gulf of Oman (hormozgan province). Thus, in total, about six genera belong to family Penaeidae are hitherto known from the Iranian coastal waters. This is the two 


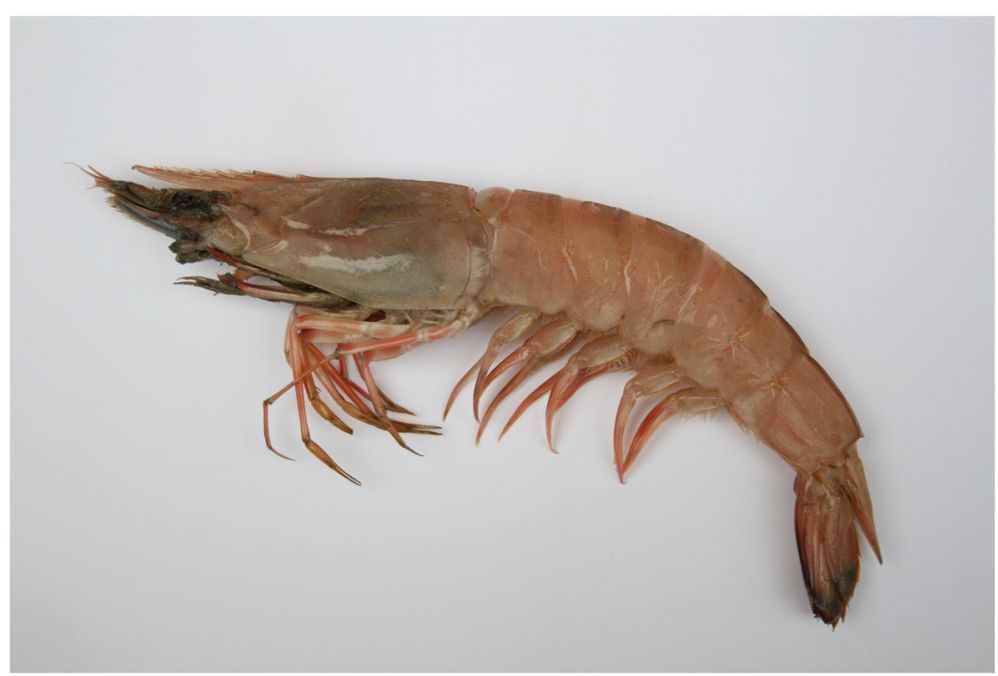

Fig. 1 Metapenaeus monoceros (Fabricius, 1798) female (C.L. 47 mm), lateral view (photo by M. Safaie)

species of the genus Metapenaeus Wood-Mason \& Alcock, 1891, was reported from the areas included Metapenaeus affinis (H. Milne Edwards, 1837) and Metapenaeus stebbengi Nobili, 1904. In the present study, we report Metapenaeus monoceros (Fabricius, 1798) from the Iranian coast of the Gulf of Oman.

\section{Methods}

Four adult specimens including three female and one male specimens of Metapenaeus monoceros (Fabricius, 1798), were collected by bottom trawl from the Gulf of Oman, the Iranian coast. Measurement of the specimens, in millimeters, is of the carapace length (C.L.) Materials examined are deposited in the Fisheries Laboratory, Hormozgan University, Iran. Terminology in the text generally follows that of Fischer and Bianchi (1984). The specimens were identified by external morphological characters.

\section{Results and discussion Systematics}

Order DECAPODA Latreille, 1802

Suborder Dendrobranchiata Bate, 1888

Family Penaeidae Rafinesque, 1815

Genus Metapenaeus Wood-Mason \& Alcock, 1891

Metapenaeus monoceros (Fabricius, 1798)

(Figures 1, 2)

For complete synonymy, see Fischer and Bianchi (1984).

\section{Materials examined}

One male (C.L. $29 \mathrm{~mm}$ ), and two females (C.L. 43, $47 \mathrm{~mm}$ ), East of Hormozgan, around Bandar Jask, Gulf of Oman $\left(25^{\circ} 32^{\prime} 570^{\prime \prime} \mathrm{N}, 58^{\circ} 26^{\prime} 390 " \mathrm{E}\right), 30-50 \mathrm{~m}$ deep, bottom trawl, coll. M. Momeni, 25 January 2013; one female (C.L. $49 \mathrm{~mm}$ ), West of Sistan va Baluchistan, around Meidani, Gulf of Oman $\left(25^{\circ} 20^{\prime} 560^{\prime \prime} \mathrm{N}, 59^{\circ}\right.$

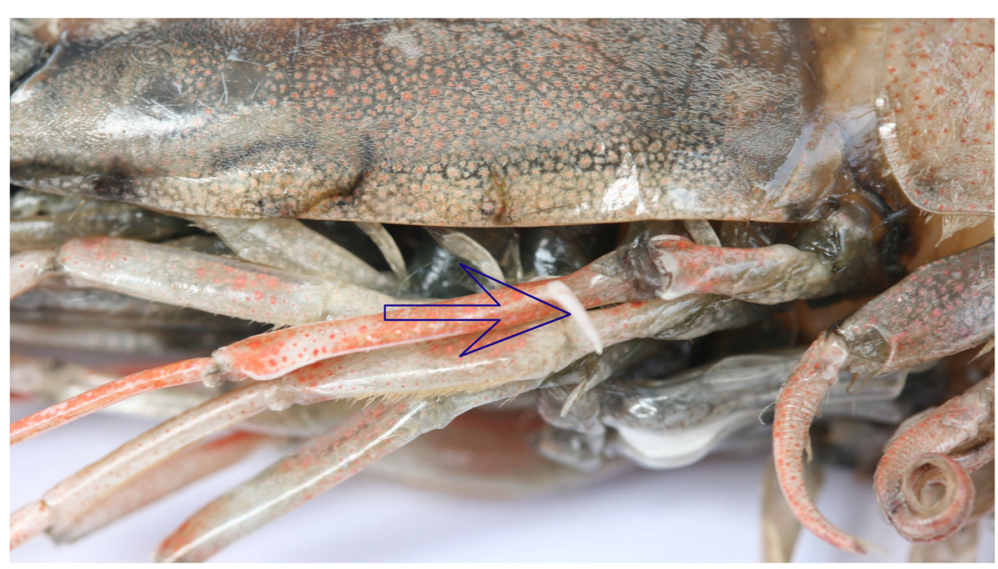

Fig. 2 Merus of fifth pereopod (male) Metapenaeus monoceros (Fabricius, 1798) with spiniform process (indicated by the arrow) (photo by M. Safaie) 
01'360"E), 30-40 m deep, bottom trawl, coll. A. Azhdahakoshpour, 5 January 2013.

\section{Description and colour pattern}

Rostrum with 9 to 10 teeth along entire dorsal margin. postrostral crest reaching posterior margin of carapace; adrostral crest ending behind second rostral tooth, adrostral groove behind epigastric tooth. A small ischial spine on first pereopod. In adult males, merus of fifth pereopod with a proximal notch followed by a long, inwardly curved spiniform process and a row of tubercles (Fig. 2); distomedian projections of petasma convoluted, greatly swollen, bulbiform, directed anterolaterally and concealing distolateral projections in ventral view. In females, anterior plate of thelycum long and deeply grooved; lateral plates with strongly raised lateral margins forming two longitudinal crests.

Body pink, with brown specks; rostral and middorsal abdominal crests brown; antennae red; pereopods and pleopods of same colour as body, sometimes more intensely pink; distal part of uropods purple-blue, external margin of exopods red.

\section{Distribution}

Speckled shrimp (Metapenaeus monoceros Fabricius, 1798) occurs from South Africa to south India, including the Red Sea, Madagascar, Mauritius, La Réunion and Sri Lanka, Further east, it extends as far as the Malay Peninsula; it has entered the eastern Mediterranean through the Suez Canal (Fischer and Bianchi 1984). Now recorded from the Iranian coasts.

\section{Conclusions}

Until now, only two species of the genus Metapenaeus Wood-Mason \& Alcock, 1891, was reported from the areas included Metapenaeus affinis (H. Milne Edwards, 1837) and Metapenaeus stebbengi Nobili, 1904. In the present study, one male and three females' speckled shrimp, Metapenaeus monoceros (Fabricius, 1798) are reported from the Iranian coast of the Gulf of Oman, for the first time. This species is native to the Indo-West Pacific from Durban to the Red Sea along the African coast and around India. It has also invaded into the eastern Mediterranean Sea through the Suez Canal. Now recorded from the Iranian coasts.

\section{Acknowledgments}

We would like to thank Dr. Toraj Valinassab and Mr. Ali Salarpouri (Iranian Fisheries Research Organization) for providing sampling opportunities.

\section{Funding}

Not applicable.

Availability of data and material Not applicable.
Authors' contributions

All authors read and approved the final manuscript. Also, agree to publish our manuscript in Marine Biodiversity records Journal.

\section{Competing interests}

The authors declare that they have no competing interests.

Consent for publication

Not applicable.

Ethics approval and consent to participate

In this study all examined specimens were by catch and discard materials.

\section{Author details}

${ }^{1}$ Fisheries Department, University of Hormozgan, Bandar Abbas, PO Box 3995, IR, Iran. ${ }^{2}$ Marine Biology and Stock Assessment Department, Persian Gulf \& Oman Sea Ecology Research Institute, Bandar Abbas, PO Box 79145-1597, IR, Iran. ${ }^{3}$ Marine Biology and Stock Assessment Department, Offshore Fisheries Research center, Chabahar, PO Box 9971779417, IR, Iran.

Received: 30 June 2016 Accepted: 1 July 2016

Published online: 01 August 2016

\section{References}

Alcock A. Materials for a carcinological fauna of India. No. 1: The Brachyura Oxyrhyncha. Part II. J Asiatic Society of Bengal. 1895;64(2):157-291.

Alcock A. Materials for a carcinological fauna of India. No. 2: The Brachyura Oxystomata. Part II. J Asiatic Society of Bengal. 1896;65(2):134-296.

Alcock A. Materials for a carcinological fauna of India. No. 3: The Brachyura Cyclometopa. Part I. The family Xanthidae. J Asiatic Society of Bengal. 1898; 67(1):67-233.

Alcock A. Materials for a carcinological fauna of India. No. 4: The Brachyura Cyclometopa. Part II. The families Portunidae, Canceridae and Corystidae. J Asiatic Society of Bengal. 1899a;68(1):1-103.

Alcock A. Materials for a carcinological fauna of India. No. 5: The Brachyura Primigenia or Dromiacea. Part II. J Asiatic Society of Bengal. 1899b;68(3):123-69.

Alcock A. Materials for a carcinological fauna of India. No. 6: The Brachyura Catometopa or Grapsoidea. Part II. J Asiatic Society of Bengal. 1900;69(2):279-456.

Alcock A. Catalogue of the Indian decapod Crustacea in the collection of the Indian Museum, Part II. Anomura. Fasciculus I. Pagurides. Calcutta: Trustees of the Indian Museum; 1905. xi, 193 pp, Plates I-XVI.

Alcock A. Catalogue of the Indian Decapod Crustacea in the collection of the Indian Museum. Part 1. Brachyura. Fasciculus 1. Introduction and Dromides or Dromiacea (Brachyura Primigenia). Calcutta; Printed by order of the trustees of the Indian museum, 1901. p. 80

Apel M. Taxonomie und Zoogeographie der Brachyura, Paguridea und Porcellanidae (Crustacea: Decapoda) des Persisch-Arabischen Golfes. Ph.D. Thesis, Johann Wolfgang Goethe-Universität, Frankfurt am Main; 2001. p. 260

Banner DM, Banner AH. Annotated checklist of the Alpheid shrimp of the Red Sea and Gulf of Aden. Zoologische Verhandelingen. 1981;190:1-99.

Carpenter KE, Krupp F, Jones DA, Zajonz U. FAO species identification guide for fishery purposes. The living marine resources of Kuwait, Eastern Saudi Arabia, Bahrain, Qatar, and the United Arab Emirates. Rome: FAO; 1997. p. 293.

Fischer W, Bianchi G. FAO species identification sheets for fishery purposes. Western Indian Ocean (Fishing Area 51), Prepared and printed with the support of the Danish International Development Agency (DANIDA), vol. 5. Rome: FAO; 1984.

Haig J. The Porcellanidae (Crustacea Anomura) of the Iranian Gulf and Gulf of Oman. Videnskabelige Meddelelser fra Dansk Naturhistorisk Forening i København. 1966;129:49-65.

Heller C. Beiträge zur Crustaceen-Fauna des Rothen Meeres. I. Theil. Sitzungsberichte der mathematisch-naturwissenschaftlichen Klasse der kaiserlichen Akademie der Wissenschaften Wien. 1861;43(1):297-374.

Naderloo R, Türkay M. Decapod crustaceans of the littoral and shallow sublittoral Iranian coast of the Persian Gulf: Faunistics, Biodiversity and Zoogeography. Zootaxa. 2012:3374:1-67.

Nobili G. Diagnoses préliminaires de 34 espèces et varieties nouvelles, et de 2 genres nouveaux de décapodes de la Mer Rouge. Bulletin du Muséum national d'Histoire, Paris. 1905;11(1):393-411.

Nobili G. Faune carcinologique de la Mer Rouge. Décapodes et Stomatopodes. Annales des Sciences naturelles (Zoologie), 9e série. 1906:4:1-347. 
Safaie M, Kamrani E. Identification and distribution of Penaeid shrimps (Crustacea: Decapoda; Brachyura; Penaeidae) of the Persian Gulf and Oman Sea

(Hormozgan Province). J Mar Res, Hormozgan University and Iranian Society of Marine Science of Technology. 2009;1 (1):15-22 (in Persian).

Stephensen K. The Brachyura of the Iranian Gulf. Danish Scientific Investigations in Iran, Part IV. E. Copenhagen: Munksgaard; 1946. p. 57-237. 